This document was prepared in conjunction with work accomplished under Contract No. DE-AC09-96SR18500 with the U. S. Department of Energy.

\title{
DISCLAIMER
}

This report was prepared as an account of work sponsored by an agency of the United States Government. Neither the United States Government nor any agency thereof, nor any of their employees, makes any warranty, express or implied, or assumes any legal liability or responsibility for the accuracy, completeness, or usefulness of any information, apparatus, product or process disclosed, or represents that its use would not infringe privately owned rights. Reference herein to any specific commercial product, process or service by trade name, trademark, manufacturer, or otherwise does not necessarily constitute or imply its endorsement, recommendation, or favoring by the United States Government or any agency thereof. The views and opinions of authors expressed herein do not necessarily state or reflect those of the United States Government or any agency thereof.

This report has been reproduced directly from the best available copy.

Available for sale to the public, in paper, from: U.S. Department of Commerce, National Technical Information Service, 5285 Port Royal Road, Springfield, VA 22161, phone: (800) 553-6847, fax: (703) 605-6900

email: orders@ntis.fedworld.gov

online ordering: http://www.ntis.gov/help/index.asp

Available electronically at http://www.osti.gov/bridge

Available for a processing fee to U.S. Department of Energy and its contractors, in paper, from: U.S. Department of Energy, Office of Scientific and Technical Information, P.O. Box 62, Oak Ridge, TN 37831-0062,

phone: (865)576-8401,

fax: (865)576-5728

email: $\underline{\text { reports@ adonis.osti.gov }}$ 
WSRC-MS-2004-00290, Rev. 0

Distribution Category: Unlimited

Keywords: DWPF, sulfate, processing limit, solubility

Retention: Permanent

\section{DEPENDENCY OF SULFATE SOLUBILITY ON MELT COMPOSITION AND MELT POLYMERIZATION (U)}

Carol M. Jantzen, Michael E. Smith, and David K. Peeler

Savannah River National Laboratory

Aiken, SC 29808

A paper for publication in the Symposium on Waste Management Technologies in Ceramic and Nuclear Industries, American Ceramic Society, Westerville, $\mathrm{OH}$ 


\title{
DEPENDENCY OF SULFATE SOLBUILITY ON MELT COMPOSITION AND MELT POLYMERIZATION
}

Carol M. Jantzen, Michael E. Smith, and David K. Peeler

Savannah River National Laboratory

Aiken, South Carolina 29808

\begin{abstract}
Sulfate and sulfate salts are not very soluble in borosilicate waste glass. When sulfate is present in excess it can form water soluble secondary phases and/or a molten salt layer (gall) on the melt pool surface which is purported to cause steam explosions in slurry fed melters. Therefore, sulfate can impact glass durability while formation of a molten salt layer on the melt pool can impact processing. Sulfate solubility has been shown to be compositionally dependent in various studies, e.g. $\mathrm{B}_{2} \mathrm{O}_{3}, \mathrm{Li}_{2} \mathrm{O}, \mathrm{CaO}, \mathrm{MgO}, \mathrm{Na}_{2} \mathrm{O}$, and $\mathrm{Fe}_{2} \mathrm{O}_{3}$ were shown to increase sulfate solubility while $\mathrm{Al}_{2} \mathrm{O}_{3}$ and $\mathrm{SiO}_{2}$ decreased sulfate solubility. This compositional dependency is shown to be related to the calculated melt viscosity at various temperatures and hence the melt polymerization.
\end{abstract}

\section{INTRODUCTION}

If the sulfate limit of a borosilicate glass is exceeded, the sulfate can form water soluble secondary phases and/or a molten salt layer (gall) on the melt pool surface. These sulfate salts, which are soluble, are often enriched in cesium and strontium, which can impact radionuclide release from the cooled glass if the salts are present as inclusions or a frozen gall layer [1]. The alkali and alkaline earth sulfate salts, in conjunction with alkali chlorides, can collect on the melt surface as a low melting $\left(600-800^{\circ} \mathrm{C}\right)$, low density, and low viscosity melt phase. At moderate concentrations, the salts have a beneficial effect on melting rates [2,3]. At excessively high feed concentrations, molten alkali sulfates float on the surface of the melt pool or become trapped as inclusions in the glass. The presence of this low viscosity (estimated to be $\sim 1$ centipoise at $1150^{\circ} \mathrm{C}$ ) melt phase increases corrosion rates of the materials of construction (off-gas, refractories primarily at the melt line, and lid heaters due to splatter). The molten salt layer is purported to enhance the potential for steam explosions in waste glass melters that are slurry fed [4]. In addition, there is potential for undesirable current paths that could deplete energy delivered to the melter due to the electrical conductivity of the molten salt layer and the formation of corrosive off-gases [5].

In order to avoid the formation of sulfate inclusions and/or the formation of a molten sulfate rich phase on the melt pool in the Defense Waste Processing Facility (DWPF), a sulfate solubility limit has been imposed since DWPF startup in 1996. The sulfate limit is expressed as $0.59 \mathrm{wt} \% \mathrm{Na}_{2} \mathrm{SO}_{4}$ which is equivalent to $0.4 \mathrm{wt} \% \mathrm{SO}_{4}{ }{ }$ in the vitrified waste form product. The $\mathrm{SO}_{4}{ }{ }^{\text {s }}$ solubility limit in the glass represents the total sulfate that the glass can accommodate from both the liquid $\left(\mathrm{Na}_{2} \mathrm{SO}_{4}\right)$ and solid $\left(\mathrm{Ca}_{2} \mathrm{SO}_{4}, \mathrm{Ba}_{2} \mathrm{SO}_{4}, \mathrm{~Pb}_{2} \mathrm{SO}_{4}\right)$ fractions of High Level Waste (HLW) sludge and not form a layer or partial layer of molten salt on the melt pool. The complete absence of a molten salt layer on the melt pool is derived from the current DWPF safety basis which eliminates any potential for steam explosions.

Ferrous sulfamate, used as a reducing agent in the separation of plutonium from uranium, is the major source of sulfate in Savannah River Site (SRS) waste. The majority of the waste sulfate is water soluble and is removed from the HLW sludge solids during washing. Therefore, 
the wastes processed in DWPF since 1996 have had insignificant quantities of sulfates in them. However, the DWPF is preparing to vitrify Sludge Batch 3 (SB3) which may contain higher than normal sulfate levels. A large portion of this $\mathrm{SO}_{4}{ }^{=}$is from ferrous sulfamate associated with the $\mathrm{NpO}_{2}{ }^{+}$that will be added to SB3 directly from SRS separations after the sludge has already been prepared. The total amount of $\mathrm{SO}_{4}{ }^{2}$ in SB3 will be higher than the sulfate processed in any of the previous DWPF sludge batches and, when processed, may exceed the current DWPF limit for $\mathrm{SO}_{4}{ }^{2}$. Therefore, the limit for $\mathrm{SO}_{4}{ }^{=}$was revisited in order to establish criteria for raising the limit without impacting safety.

\section{BACKGROUND}

Sulfate Saturation and Volatility

Sulfate solubility is difficult to determine because of supersaturation effects. Different researchers define sulfate solubility phenomenologically in terms of physical observations, e.g. vacuoles or inclusions in frozen glass generated in crucible or dynamic melter tests, complete or partial molten layer observations in melter tests, complete or partial frozen sulfate layers observed in quenched crucible tests. These phenomenological observations describe different "degrees of saturation" of the melt (or quenched melt).

Walker [4] was the first to describe the varying degrees of sulfate saturation in detail. Walker noted that in the presence of excess sulfate (when a heavy layer of gall was present) that the glass was "supersaturated" and $\mathrm{Na}_{2} \mathrm{SO}_{4}$ vacuoles formed in the glass. More sulfate was retained in the glass if it were in equilibrium with a layer of molten $\mathrm{Na}_{2} \mathrm{SO}_{4}$ than if the glass were in equilibrium with the gaseous $\mathrm{SO}_{2}$ in the melter plenum, e.g. supersaturation could be induced by high $p_{\mathrm{SO}_{2}}$ and the formation of a layer of gall which inhibited $\mathrm{SO}_{2}$ volatilization. Subsequently, the amount of saturation of the melt was determined to depend strongly on feed rate and reductant concentration in addition to sulfate concentration in the feed [6]. Faster feed rates were found to allow a molten salt layer to accumulate. Therefore, during this modeling effort, the phenomenological observations from different static crucible and dynamic melter tests were systematized based on the "degree of saturation" criteria given in Table 1.

Saturation with respect to $\mathrm{Na}_{2} \mathrm{SO}_{4}$ is actually saturation with respect to a "mixed salt layer" since the salt contains chlorides, fluorides, chromates [7], and other sulfates, e.g. $\mathrm{CaSO}_{4}[3,7,8]$.

Table 1 Degree of Saturation Criteria

\begin{tabular}{cc}
\hline Degree of Saturation & Melt Pool/Glass Surface \\
\hline Under & No gall present \\
At & No gall present \\
Over & Partial coverage of surface with gall \\
& Complete coverage of surface with \\
Super & gall and/or vacuoles or secondary \\
& phase observed in glass after cooling \\
\hline
\end{tabular}

Determination of sulfur saturation is complex because sulfur can volatilize by different reaction paths depending on the melt temperature, the sodium content, the REDuction/OXidation (REDOX) equilibrium, and the $p_{\mathrm{SO}_{2}}$ inside the melter plenum or crucible vapor space. The $p_{\mathrm{SO}_{2}}$ and the REDOX equilibrium combine to alter the type of sulfur species that vaporize and the amount of each species that vaporizes. For example, reducing REDOX conditions [9] and/or higher temperatures in a melter will force oxidized $\mathrm{SO}_{4}{ }^{=}$species to the $\mathrm{S}^{2-}$ ion as $\mathrm{SO}_{2}(\mathrm{~g})$. If the 
system is open or has a low $p_{\mathrm{SO}_{2}}$ in the plenum or vapor space then the reaction shown in Equation 1 wants to progress to the right hand side (RHS) and liberate $\mathrm{SO}_{2}(\mathrm{~g})$. If the system is closed and there is a high $p_{\mathrm{SO}_{2}}$ in the plenum or vapor space then the equilibrium in Equation 1 is shifted to the left hand side (LHS) and the sulfate vaporization is inhibited. Likewise, oxidizing REDOX conditions [9] allow the $\mathrm{SO}_{4}{ }^{2}$ to decompose to the $\mathrm{SO}_{4}{ }^{2=}$ ion and vaporize as $\mathrm{Na}_{2} \mathrm{SO}_{4}$ which can condense in the melter off-gas line and be problematic [10,11]. If the system is open with respect to $\mathrm{p}_{\mathrm{SO}_{2}}$ then Equation 2 proceeds to the RHS. This equilibrium to the RHS is accelerated if a melter is aggressively bubbled with oxygen or air [12]. However, if the $p_{\mathrm{SO}_{2}}$ is high in the plenum or vapor space then the release of $\mathrm{Na}_{2} \mathrm{SO}_{4}$ in Equation 2 is inhibited, and the equilibrium is forced to the LHS.

$$
\begin{gathered}
2 \mathrm{Na}_{2} \mathrm{SO} 4 \leftrightarrow 2 \mathrm{Na}_{2} \mathrm{O}+2 \mathrm{SO}_{2} \uparrow+\mathrm{O}_{2} \uparrow \\
2 \mathrm{Na}_{2} \mathrm{SO}_{4} \leftrightarrow 2 \mathrm{Na}_{2} \mathrm{SO}_{4} \uparrow
\end{gathered}
$$

Moreover, higher temperatures, e.g. in the range of $1250-1400^{\circ} \mathrm{C}$, and the addition of $\mathrm{SiO}_{2}$ to a melt forces the decomposition of $\mathrm{Na}_{2} \mathrm{SO}_{4}$ to $\mathrm{SO}_{2}$ per the Keppler reaction [13]

$$
\mathrm{Na}_{2} \mathrm{SO}_{4}+x \mathrm{SiO}_{2} \rightarrow \mathrm{Na}_{2} \mathrm{O} \bullet x \mathrm{SiO}_{2}+\mathrm{SO}_{2} \uparrow+0.5 \mathrm{O}_{2}
$$

The literature suggests that in conventional Joule heated melters (without bubbling) the sulfate volatility is between 40-70 wt\% depending on REDOX, melt temperature, and melt viscosity. Sulfate volatility affords an extra margin of safety when setting a $\mathrm{SO}_{4}{ }^{=}$solubility limit because no credit is taken for the volatility of $\mathrm{SO}_{4}{ }^{=}$when the soluble and insoluble $\mathrm{SO}_{4}{ }^{2}$ concentration in the sludge is mathematically converted into the $\mathrm{SO}_{4}{ }^{2}$ glass solubility limit. The range of measured volatility based on various glasses, including those from nuclear waste glass studies, commercial glass studies, and even a mining waste study are very similar:

- $\quad 75 \%$ of the $\mathrm{Na}_{2} \mathrm{SO}_{4}$ was vaporized in a pilot scale melter test at $1150^{\circ} \mathrm{C}$ with a high alumina containing glass having a viscosity of 160 poises [14]

- $\quad-50 \%$ of the total sulfur (as S) was vaporized in a pilot scale melter demonstration [6]. Higher reductant content vaporized $\sim 70 \%$ to the off-gas as $\mathrm{SO}_{2}$ gas at $\mathrm{Fe}^{+2} / \Sigma \mathrm{Fe}$ REDOX ratios of 0.8 , well above the $\mathrm{Fe}^{+2} / \Sigma \mathrm{Fe}$ limit of 0.33 to prevent nickel sulfide precipitation [15].

- $\sim 45 \%$ of the total sulfate was vaporized in crucible tests when the mining waste was coupled with Frit 165 [16]

- $36-42 \%$ of the $\mathrm{SO}_{4}{ }^{=}$is vaporized during routine commercial glass vitrification [14]

- $\sim 40 \%$ of the $\mathrm{SO}_{4}{ }^{=}$vaporized during Slurry-Fed Melt Rate Furnace (SMRF) testing reported in this study on $\mathrm{SB} 3$ feeds at a target $\mathrm{REDOX}$ of $\mathrm{Fe}^{+2} / \Sigma \mathrm{Fe}=0.2$.

- $\quad 55 \%$ of the $\mathrm{Na}_{2} \mathrm{SO}_{4}$ vaporized during pilot scale testing at $1150^{\circ} \mathrm{C}$ [3]

Previous Sulfate Solubility Modeling

A model for sulfate solubility was developed by Papadopoulos [17] in 1973 for soda-limesilica melts. In this model, the number of bridging oxygen $\left(\mathrm{O}^{0}\right)$, free oxygen $\left(\mathrm{O}^{2-}\right)$, and nonbridging oxygen $\left(\mathrm{O}^{-}\right)$are related to the dissociation of $\mathrm{SO}_{4}{ }^{=}$by the equilibrium $\mathrm{O}^{0}+\mathrm{O}^{2-} \cdot 2 \mathrm{O}^{-}$ and $\mathrm{SO}_{4}^{2-} \leftrightarrow \mathrm{SO}_{3}+\mathrm{O}^{2-}$. Combining the equilibrium constants $\left(\mathrm{K}_{\mathrm{A}}\right.$ and $\left.\mathrm{K}_{\mathrm{B}}\right)$ of these two 
equations provides the relationship $\left[\mathrm{SO}_{4}^{2-}\right] \propto \frac{p_{\mathrm{SO}_{3}}\left[\mathrm{O}^{-}\right]^{2}}{\mathrm{~K}_{\mathrm{A}} \mathrm{K}_{\mathrm{B}}\left[\mathrm{O}^{0}\right]}$ where $P_{\mathrm{SO}_{3}}$ is the partial pressure of $\mathrm{SO}_{3}$ in the melter atmosphere and $\left[\mathrm{SO}_{4}^{2-}\right]$ is the sulfate solubility in the glass. Papadopoulos defined a linear relationship between the chemical composition parameter $\left[\mathrm{O}^{-}\right]^{2} /\left[\mathrm{O}^{0}\right]$, which is also known as the ratio of [non bridging oxygen $]^{2} /\left[\right.$ bridging oxygen] or $[\mathrm{NBO}]^{2} /[\mathrm{BO}]$, and $\left[\mathrm{SO}_{4}^{2-}\right]$ retained in various commercial glasses when the melt temperature and the $P_{\mathrm{SO}_{3}}$ above the melt were constant. The dependency of the sulfate solubility on $\left[\mathrm{O}^{-}\right]^{2} /\left[\mathrm{O}^{0}\right]$ was confirmed by Ooura and Hanada [18] in 1998 for a series of alkali-silicate and alkaline earth-lime-silica glasses including $\mathrm{Ba}, \mathrm{Sr}, \mathrm{Pb}, \mathrm{Ca}, \mathrm{Mg}$, and $\mathrm{Zn}$ species. The $\left[\mathrm{O}^{0}\right]$ concentration was calculated as twice the $\mathrm{SiO}_{2}$ mol\% minus the alkali oxide $(\mathrm{mol} \%)$ while the $\left[\mathrm{O}^{-}\right]$was calculated as twice the $\mathrm{R}_{2} \mathrm{O}$ $(\mathrm{mol} \%)$ of the glass. Ooura and Hanada defined a linear relationship between the $\left[\mathrm{O}^{-}\right]^{2} /\left[\mathrm{O}^{0}\right]$ glass composition term and sulfate solubility. The sulfate solubility increased as the alkali content of the melt increased.

In 2001, Li et.al. [19] modified the Papadopoulos $\left[\mathrm{O}^{-}\right]^{2} /\left[\mathrm{O}^{0}\right]$ parameter to include many of the species found in simulated nuclear waste glasses, e.g. $\mathrm{B}_{2} \mathrm{O}_{3}, \mathrm{Fe}_{2} \mathrm{O}_{3}, \mathrm{Al}_{2} \mathrm{O}_{3}$. $\mathrm{Li}$ assumed that $\mathrm{B}$, $\mathrm{Fe}$, and $\mathrm{Al}$ were all network formers, e.g they formed $\mathrm{NaBO}_{3}, \mathrm{NaFeO}_{2}$, and $\mathrm{NaAlO}_{2}$ structural groups, in order to predict sulfate solubility in waste glasses being considered for stabilization of Hanford Low Activity Waste (LAW). Use of the modified NBO term in the Li study caused the relationship between $\left[\mathrm{O}^{-}\right]^{2} /\left[\mathrm{O}^{0}\right]$ composition term and the sulfate solubility to be parabolic instead of linear. In addition, the $P_{\mathrm{SO}_{3}}$ of the melts studied was not controlled nor considered. Two distinct trends were observed when the data was modeled although the sulfate solubility did increase as the alkali content of the melt increased as found in previous studies $[17,18]$.

Another empirical sulfate solubility model known as the "rule of five" was developed for Hanford LAW waste glasses [20]. This empirical model suggests that sulfate solubility decreases with increasing alkali content, a trend completely opposite from all previous studies $[17,18,19]$. This empirical model is based on the wt\% of $\mathrm{SO}_{3}\left(w_{\substack{\max \\ S O_{3}}}\right)$ and the wt\% of $\mathrm{Na}_{2} \mathrm{O}$ $\left(w_{\mathrm{Na}_{2} \mathrm{O}}\right)$ in the glass and is expressed as $w_{\substack{\mathrm{max}_{3} \\ \mathrm{SO}_{3}}}=\frac{5}{w_{\mathrm{Na}_{2} \mathrm{O}}}$. The waste glasses modeled by Li [19] and Pegg [20] contained only $\leq 2.5 \mathrm{wt} \% \mathrm{Fe}_{2} \mathrm{O}_{3}$ compared to $\sim 12 \mathrm{wt} \%$ in DWPF waste glasses.

\section{SULFATE SOLUBILITY MODELING AND VALIDATION DATABASES}

A broad range of literature and experimental data on sulfate solubility was surveyed (see Table 2) to construct a sulfate solubility versus glass composition database that included both LAW glasses with low $\mathrm{Fe}_{2} \mathrm{O}_{3}$ content and High Level Waste (HLW) waste glasses with high $\mathrm{Fe}_{2} \mathrm{O}_{3}$ contents. The data surveyed included both crucible and pilot scale melter tests on both SRS HLW glasses [1,3,4,7,8,14,21,22] Hanford LAW glasses [6,33,34,35], and European intermediate level nuclear waste glasses [23]. All of the glasses were classified as either at or under saturation with respect to sulfate if the melt pool surface in a pilot scale melter and or the solidified glass surface observed in a crucible had no sulfate deposits or gall present. Glasses were classified as supersaturated with respect to sulfur if there were heavy surface deposits and gall present and sulfur vacuoles and or secondary phases in the bulk glass. Glasses were 
classified as over saturated if some surface sulfate deposits were observed and there were no vacuoles or secondary sulfate phases in the bulk glass (see Table 1). This classification partially addresses the varying $P_{\mathrm{SO}_{3}}$ experienced during experimentation due to different amounts of melt pool coverage by gall.

If the literature did not adequately describe the visual appearance of the melt pool, glass surface, and/or bulk glass [21], if the literature did not adequately measure the sulfate in the final glass [1,22], or if the literature study overwhelmed the melt system with reductant [6] at REDOX values unachievable in Joule heated melters, e.g. $\mathrm{Fe}^{+2} / \Sigma \mathrm{Fe}>0.33$, then the data were excluded from the modeling database. All of the data given in Table 2 met the glass description criteria, the REDOX criteria, and sulfate measurement criteria. Note that only borosilicate glasses are included in the current evaluation. Details of all of the data surveyed are given in Reference 24.

It is noteworthy that about half of the sulfate solubility data given in Table 2 is data from pilot scale melters. Most notably, between 1983 and 1984 three Engineering Scale Ceramic Melter (ESCM) pilot scale campaigns were performed at the Pacific Northwest National Laboratory (PNNL). Each melter campaign was 10 days and processed average composition SRS waste (Stage 1) mixed with Frit 165 [8]. The $\mathrm{SO}_{4}{ }^{=}$in the feed was from both soluble $\mathrm{Na}_{2} \mathrm{SO}_{4}$ and insoluble $\mathrm{CaSO}_{4}$. The data from the ESCM-3B campaign is the basis for the current DWPF sulfate glass limit of $0.4 \mathrm{wt} \% \mathrm{SO}_{4}{ }^{=}$.

Additional sulfate solubility data was developed in a Slurry-Fed Melt Rate Furnace (SMRF) with simulated DWPF SB3. The first test (SMRF-124) was performed at $31 \mathrm{wt} \%$ waste loading while the second test (SMRF-125) was performed at $35 \mathrm{wt} \%$ waste loading. The target sulfate concentration in the feeds were 0.47 and $0.52 \mathrm{wt} \% \mathrm{SO}_{4}{ }^{\circ}$ on a calcined oxide basis, respectively. The resulting measured sulfate in the glasses formed were 0.29 and $0.53 \mathrm{wt} \% \mathrm{SO}_{4}{ }^{\text {, }}$, respectively. No sulfate was visually observed on the melt pool (see Table 2).

The validation data was generated at SRS by Peeler and Smith [25] and is summarized in Table 3. In these studies DWPF SB3 compositions were tested in crucibles and in the Slurry-fed Melt Rate Furnace (SMRF). The criteria was to define the maximum $\mathrm{SO}_{4}{ }^{=}$in the glass with no visual observation of gall on the glass surface. In the crucible study both batch chemicals (bc) and precipitated sludge were used. There was no reductant in the batch chemical tests but the precipitated sludge was made at a target REDOX of $\mathrm{Fe}^{+2} / \Sigma \mathrm{Fe}$ of 0.2 (adjusted with a combination of formic and nitric acids). The crucibles were sealed with nepheline gel which inhibited vaporization of $\mathrm{SO}_{2}(\mathrm{~g})$ and imparted a high $p_{\mathrm{SO}_{2}}$ in the vapor space of the crucibles thereby forcing Equations 1 and 2 to the left and inhibiting $\mathrm{SO}_{2}(\mathrm{~g})$ vaporization. In the SMRF studies precipitated sludge made at a REDOX target of 0.2 was also used but the SMRF is open to $\mathrm{SO}_{2}(\mathrm{~g})$ vaporization.

\section{SULFATE SOLBUILITY AS A FUNCTION OF GLASS POLYMERIZATION}

The literature surveyed while compiling the databases maintained that many individual oxides had an impact on sulfate solubility in glass but that overall compositional dependency of sulfate solubility had here-to-fore not been determined. Melt melt de-polymerizers like $\mathrm{B}_{2} \mathrm{O}_{3}$ [1,34], $\mathrm{Li}_{2} \mathrm{O}$ [26], $\mathrm{CaO}$ and $\mathrm{MgO}$ [34,27], $\mathrm{Na}_{2} \mathrm{O}$ [4,18, 28], and $\mathrm{Fe}_{2} \mathrm{O}_{3}$ [4] were all shown to increase sulfate solubility while $\mathrm{Al}_{2} \mathrm{O}_{3}[4,17]$ and $\mathrm{SiO}_{2}$ [13,17], melt polymerizers, decreased sulfate solubility $[4,28]$.

The glass species cited in the above studies are the predominant polymerization (bridging oxygens) and depolymerization (non-bridging oxygen) terms in the DWPF viscosity model [29] given by 


$$
\log \eta(\text { poise })=-0.61+\left(\frac{4472.45}{T\left({ }^{\circ} C\right)}\right)-(1.534 * N B O)
$$

where $\mathrm{NBO}=\underline{2\left(\mathrm{Na}_{2}\right.} \underline{\mathrm{O}+\mathrm{K}_{2}} \underline{\mathrm{O}+\mathrm{Cs}_{2}} \frac{\mathrm{O}+\mathrm{Li}_{2}}{\mathrm{SiO}_{2}} \underline{\mathrm{O}+\mathrm{Fe}_{2}} \underline{\mathrm{O}}_{3} \underline{-\mathrm{Al}_{2}} \underline{\mathrm{O}}_{3} \underline{)}+\mathrm{B}_{2} \underline{\mathrm{O}}_{3}$

The DWPF viscosity model assumes that a pure $\mathrm{SiO}_{2}$ glass is fully polymerized and that each mole of alkali oxide added creates two non-bridging oxygen bonds, e.g. depolymerizes the glass. Each mole of $\mathrm{Al}_{2} \mathrm{O}_{3}$ creates two bridging oxygen bonds (polymerizes the glass structure) by creating tetrahedral alumina groups that bond to the $\mathrm{NaAlO}_{2}$ structural groups as in the $\mathrm{Li}$ et. al [19] model. In $\mathrm{Al}_{2} \mathrm{O}_{3}$ and/or $\mathrm{SiO}_{2}$ deficient glasses, $\mathrm{Fe}_{2} \mathrm{O}_{3}$ can take on a tetrahedral coordination and polymerize a glass by forming $\mathrm{NaFeO}_{2}$ structural groups as assumed in the Li et.al. [19] model. However, if sufficient $\mathrm{Al}_{2} \mathrm{O}_{3}$ and $\mathrm{SiO}_{2}$ are present in a glass, $\mathrm{Fe}_{2} \mathrm{O}_{3}$ is octahedral and creates two non-bridging oxygen bonds, e.g. it depolymerizes the glass matrix as assumed in the DWPF viscosity model (Equation 4). This is consistent with the work of Mysen [30] who demonstrated that in high iron magmas (iron silicate glasses) at levels of $10 \mathrm{wt} \%$ that $\mathrm{Fe}_{2} \mathrm{O}_{3}$ decreased the melt viscosity. He concluded that $\mathrm{NaFeO}_{2}$ structural groups were not incorporated into the glass network to the same degree as $\mathrm{NaAlO}_{2}$ structural groups [30]. Lastly, the DWPF viscosity model assumes that each mole of $\mathrm{B}_{2} \mathrm{O}_{3}$ creates one non-bridging oxygen bond. This is based on a data by Smets and Krol [31], and Konijnendijk [32] who demonstrated that for sodium silicate glasses with low $\mathrm{B}_{2} \mathrm{O}_{3}$ content that $\mathrm{B}_{2} \mathrm{O}_{3}$ enters the glass network as $B O_{4}^{-}$ tetrahedra that contribute no NBO while at higher concentrations these tetrahedra are converted into planar $\mathrm{BO}_{3}^{-}$groups that contribute one non-bridging oxygen atom. The latter is assumed in the DWPF viscosity model.

The DWPF viscosity is model is used in this study rather than the NBO term since the relation of viscosity to glass structure is temperature dependent and the DWPF viscosity model is a three dimensional spline fit which includes NBO, log viscosity, and temperature. This is significant for modeling sulfate solubility as a function of viscosity since glasses of varying melt temperatures were modeled. In addition, the sulfate solubility boundary was determined to be temperature dependent [33].

The compositions given in Table 2 were used to calculate the glass viscosity used in the sulfate solubility model as given in Equation 4. If an alternate NBO term is used that includes a $\mathrm{CaO}$ term and it is assumed that a mole of $\mathrm{CaO}$ creates two non-bridging oxygen bonds as does a mole of alkali oxide, then the model fit, in terms of $\mathrm{R}^{2}$, is greatly improved. For brevity only the dependency of the sulfate solubility on the DWPF viscosity model is discussed. The usage of a $\mathrm{CaO}$ term is discussed in detail elsewhere [24].

Modeling of the sulfate solubility as a function of calculated viscosity from Equation 4 was performed. The glasses were grouped by sulfate saturation based on the definitions given in Table 1. This provided a series of three parallel models, one at saturation, one at over saturation, and one at supersaturation as shown in Figure 1 and given below:

$$
\begin{aligned}
& \left(\mathrm{SO}_{4}{ }^{=} \mathrm{wt} \%\right) \text { )"at saturation" }=1.299-0.5501 \log \text { viscosity }_{\text {calc }} \text { (poise) } \quad \mathrm{R}^{2}=0.88 \\
& \left(\mathrm{SO}_{4}{ }^{=} \mathrm{wt} \%\right) \text { "over satuation" }=1.7810-0.5650 \log \text { viscosity }_{\text {calc }} \text { (poise) } \quad \mathrm{R}^{2}=0.76 \\
& \left(\mathrm{SO}_{4}{ }^{=} \mathrm{wt} \%\right) \text { "supersatuation" }=2.016-0.4681 \log \text { viscosity } \text { calc }_{\text {(poise })} \quad \mathrm{R}^{2}=0.90
\end{aligned}
$$


Table 2 Glass Compositions (Wt\%), Sulfate Solubility (Wt\%), and Calculated Viscosity (Poise) For Model Data

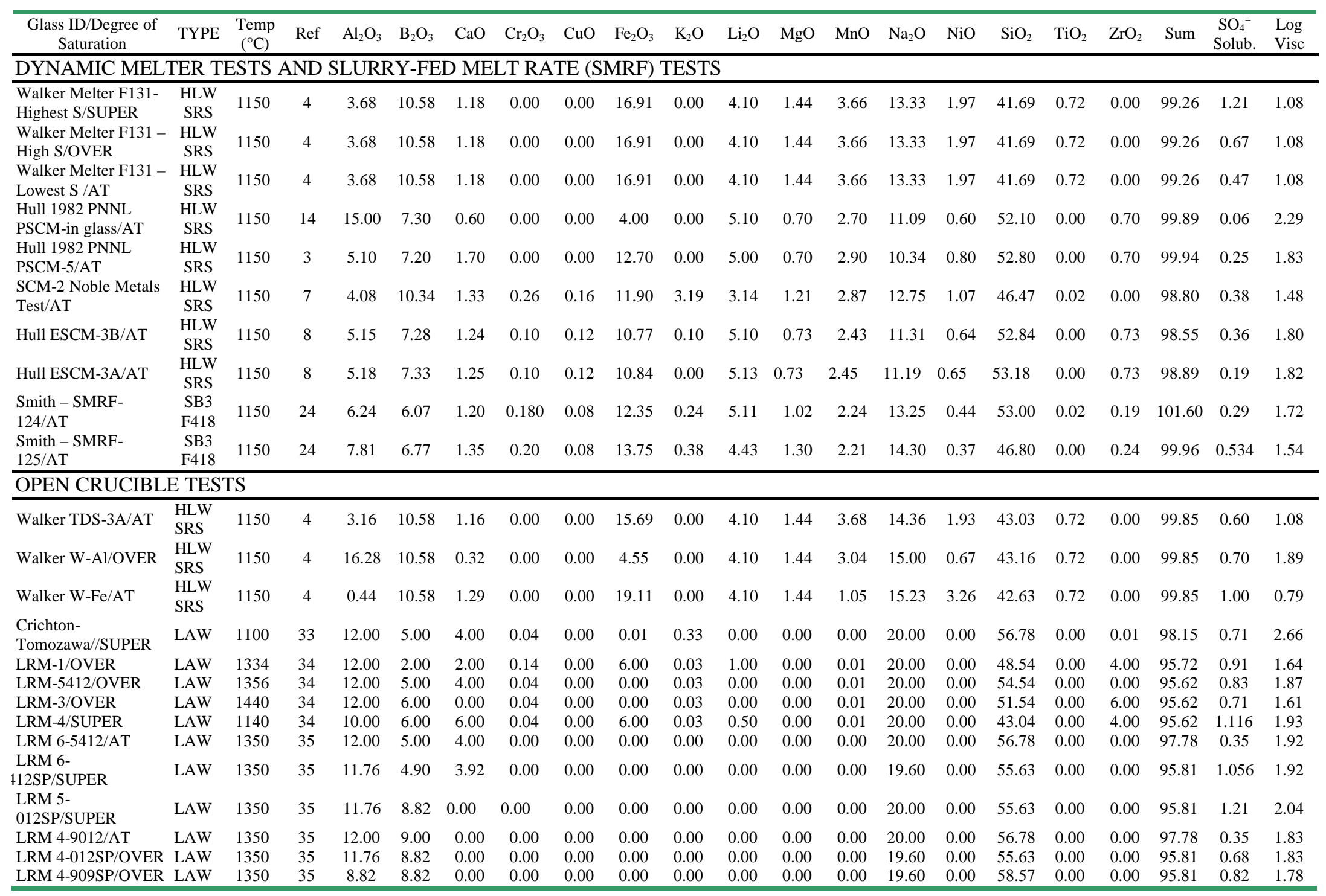


Table 3 Glass Compositions (Wt\%), Sulfate Solubility (Wt\%), and Calculated Viscosity (Poise) For Validation Data

\begin{tabular}{|c|c|c|c|c|c|c|c|c|c|c|c|c|c|c|c|c|c|c|c|c|c|}
\hline $\begin{array}{c}\text { Glass ID/Degree of } \\
\text { Saturation }\end{array}$ & & $\begin{array}{l}\text { Temp } \\
\left({ }^{\circ} \mathrm{C}\right)\end{array}$ & Ref & $\mathrm{Al}_{2} \mathrm{O}_{3}$ & $\mathrm{~B}_{2} \mathrm{O}_{3}$ & $\mathrm{aO}$ & $\mathrm{Cr}_{2} \mathrm{O}_{3}$ & $\mathrm{CuO}$ & $\mathrm{Fe}_{2} \mathrm{O}_{3}$ & $\mathrm{~K}_{2} \mathrm{O}$ & $\mathrm{Li}_{2} \mathrm{O}$ & $\mathrm{Mo} \Omega$ & $\mathrm{MnO}$ & $\mathrm{Na}_{2} \mathrm{O}$ & $\mathrm{NiO}$ & $\mathrm{SiO}_{2}$ & $\mathrm{TiO}_{2}$ & $\mathrm{ZrO}_{2}$ & Sum & $\begin{array}{l}\mathrm{SO}_{4}{ }^{=} \\
\text {Solub. }\end{array}$ & $\begin{array}{l}\text { Log } \\
\text { Visc }\end{array}$ \\
\hline \multicolumn{22}{|c|}{ SLURRY-FED MELT RATE (SMRF) TESTS } \\
\hline SMRF-124/AT & SB3 & 1150 & 25 & 6.6 & & & & & & & & & & 14 & & 47.1 & & 0.13 & & 0.76 & 1.53 \\
\hline s-bc-100-30/AT & SB3 & 1150 & 25 & & & & & & & & & & & & & & & & & 0.61 & 1.78 \\
\hline AT & SB3 & 1150 & 25 & & & & & 0.06 & & & & & & & & & & & .22 & & 1.66 \\
\hline AT & SB3 & 1150 & 25 & 58 & 5.18 & & & 0.06 & & & & & 25 & 07 & .42 & & & & & .73 & 1.64 \\
\hline AT & SB3 & 1150 & 25 & & 5.11 & & & & & & & & & & & & & & & 0.77 & .56 \\
\hline s-bc-5 & SB3 & 1150 & 25 & & 5.48 & 1.0 & & 0.07 & & ( & & & 2 & & & & 0 & .11 & .05 & 0.49 & 1.84 \\
\hline s-bc-5 & SB3 & 1150 & 25 & 5.89 & 5.57 & 1.17 & & 0.07 & & 0 & & 1.45 & 2.14 & 12.32 & 0.43 & 53.47 & 0 & .11 & 101.06 & 0.54 & 1.76 \\
\hline$s-b c-50$ & SB3 & 1150 & 25 & 6.6 & 5.05 & 1.27 & & 0.07 & & 0 & 5.11 & 1.49 & 2.24 & & 0.46 & 52 & 0 & .12 & 100.7 & 0.59 & 1.74 \\
\hline$s-b c-5$ & SB3 & 1150 & 25 & 6.38 & 5.09 & 1.32 & & 0.08 & & 0 & & 1.58 & 2.33 & & 0.47 & & 0 & & & 0.59 & 1.65 \\
\hline$s-b c-50$ & SB3 & 1150 & 25 & 7.03 & 4.67 & 1.48 & & 0.09 & & 0 & & 1.7 & 2.58 & 61 & 0.48 & .53 & 0 & .14 & .79 & 0.64 & 1.57 \\
\hline s-bc-50 & SB3 & 1150 & 25 & & 4.2 & & & & & 0 & & 2.02 & 3.05 & & & & 0 & & & 0.66 & 1.35 \\
\hline /AT & B3 & 1150 & 25 & & 5.67 & & & & & 0 & & & 1.76 & & 0.42 & & 0 & 0.22 & & 0.49 & 1.84 \\
\hline & B3 & 1150 & 25 & & & & & & & 0 & & & 2 & & 0.47 & & 0 & 0.24 & & 0.51 & 1.79 \\
\hline$p-10$ & SB3 & 1150 & 25 & & & & & & & 0 & & & 2.05 & & & & 0 & & & 0.54 & 1.76 \\
\hline s-sp- & B3 & 11 & & & & 1. & & 0 . & & & & & 2.28 & 12.68 & & & & & & 0.47 & 1.66 \\
\hline s-sp- & SB3 & 115 & 2 & & 4.8 & 1. & & 0.06 & & & & & 2.5 & & 0. & & & .31 & & 0.66 & 1.55 \\
\hline s-sp-1 & SB3 & 115 & 25 & 8.13 & 4.88 & 1. & & 0.06 & 17 & 0 & 4. & 1. & 2.55 & 13.13 & 0.61 & 44.99 & & 0.32 & & 0.72 & 1.50 \\
\hline s-sp-5c & SB3 & 1150 & 25 & 6.3 & 5.4 & 0.98 & 0.08 & 0.07 & 12.07 & 0 & & & 1.68 & 11.55 & & & o & 0.22 & 100.18 & 0.38 & 1.88 \\
\hline s-sp-50-3 & SB3 & 1150 & 25 & 6.05 & 5.24 & 1.12 & & 0.08 & & 0 & 5.18 & 1.43 & 1.91 & 11.79 & 0.47 & 52.74 & 0 & 0.25 & 99.65 & 0.49 & 1.79 \\
\hline s-sp-5 & SB3 & 1150 & 25 & & 5.06 & 1.1 & & 0.08 & 13.99 & 0 & & 1.44 & 1.99 & 11.92 & 0.47 & & 0 & 0.26 & 99.43 & 0.46 & 1.76 \\
\hline s-sp-5 & SB3 & 1150 & 25 & 6.78 & 4.89 & 1.2 & 0.09 & 0.08 & & 0 & & 1.54 & 2.15 & 12.31 & 0.48 & 49.39 & 0 & 0.27 & 98.91 & 0.48 & 1.70 \\
\hline s-sp-5 & SB3 & 1150 & 25 & 7.39 & 4.8 & 1.3 & & 0.09 & 15.92 & 0 & 4.7 & 1.63 & 2.3 & 12.73 & 0.52 & 48.26 & 0 & 0.29 & 100.15 & 0.5 & 1.65 \\
\hline s-sp-50-45/AT & SB3 & 1150 & 25 & 8.38 & 4.57 & 1.52 & 0.11 & 0.1 & 17.82 & 0 & 4.43 & 1.84 & 2.59 & 13.35 & 0.6 & 44.31 & 0 & 0.33 & 99.95 & 0.56 & 1.51 \\
\hline
\end{tabular}


The "at saturation" model is based on 12 data points most of which are pilot scale melter tests and SMRF tests, only one crucible study is included. The melter runs span well beyond current DWPF viscosity limits of 20 and 110 poise since melter testing in the early 1980's was performed to define the DWPF viscosity operational limits. The "supersaturation model" is based on 5 data points and also includes melter and crucible studies that span well beyond the DWPF viscosity limits of 20 and 110 poise. The "over saturation" model (Equation 6) is more difficult to define since it includes variable sulfate layer coverage and is developed primarily on Hanford glass compositions (5 data points) and only 2 DWPF glass compositions. Both melter and crucible data are included. Thus the "over saturation" model (Equation 6) has the lowest $\mathrm{R}^{2}$ goodness of fit.

It can be argued that Equation 5 is very conservative in that it is an "at saturation" to just under saturated sulfate solubility limit in glass that is applied to the feed composition. Hence, the glass solubility limit does not account for sulfate volatility in a melter which has been shown to be $\sim 40 \%$ for melts of DWPF as well as for melts of different composition, viscosity and REDOX.

Therefore, a recommendation was made that a melter operational limit be set at the upper $95 \%$ confidence (U95) of the individual predicted $\mathrm{SO}_{4}{ }^{=}$values representing "at saturation." The U95 limit remains extremely conservative compared to both the over saturated and the supersaturated sulfate in glass solubility models while allowing more $\mathrm{SO}_{4}{ }^{2}$ to be processed in the DWPF melter given the safety basis constraint of no visible sulfate layer or partial sulfate layer [24].

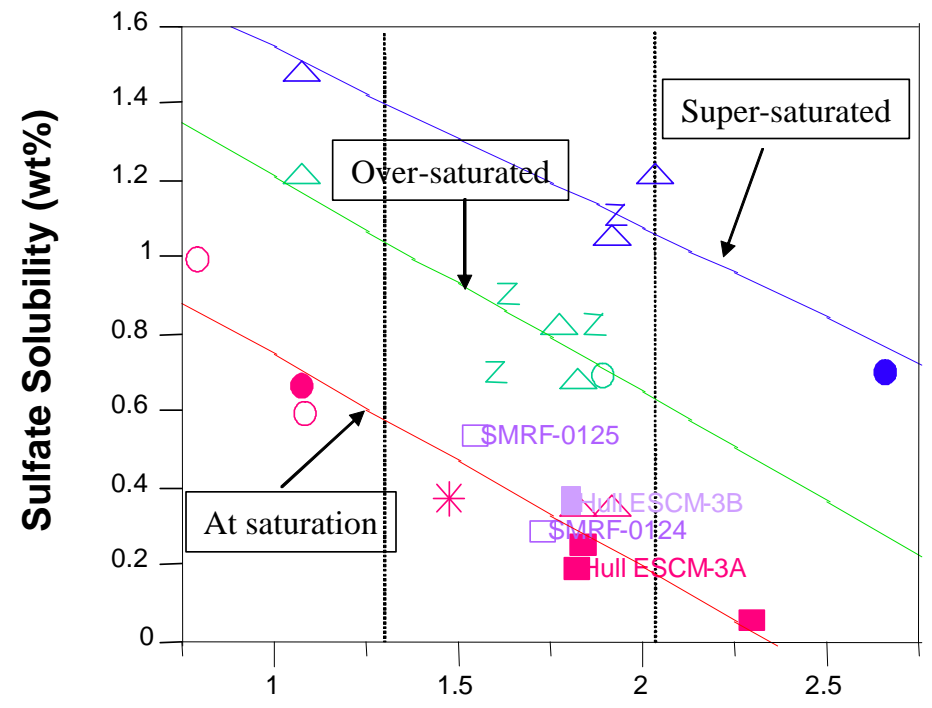

Log Viscosity (poise)

Figure 1. Model data used to define three separate sulfate saturation models as a function of melt polymerization and temperature, e.g. melt viscosity (poise). The DWPF viscosity limits of 20 poise (1.3 log viscosity) and 110 poise (2.04 log viscosity) are shown for reference.

The usage of Equation 5 as a conservative "at saturation" sulfate model was verified with the SB3 specific SMRF data which represented an open system, e.g. open to volatilization, and with sealed crucible data [25]. In the closed crucible tests the data given in Table 3 was adjusted for $40 \%$ vaporization to simulate the volatilization experienced in all the open system tests modeled in this study (see Table 2). While no volatilization was observed of the tests run with batch 
chemicals (samples in Table 3 that include the letters bc) there was some minor volatilization of the sulfur in the tests run with SRAT product (sample identifications in Table 3 include the letters sp). Recognizing that application of the $40 \%$ volatilization factor for the sealed crucible tests is an approximation, this does demonstrate that the SMRF and crucible data for SB3 validates the "at saturation" sulfate solubility correlation (Figure 2). If the closed crucible data is not adjusted for volatilization then it validates the U95 of Equation 5 verifying the operational limit recommended to avoid sulfate accumulation in a waste glass melter [24].

The sulfate solubility-melt viscosity model presented in this study is linear like the Papadopoulos [17] model. A regression of the NBO term from Equation 4 with a $\mathrm{CaO}$ and an $\mathrm{MgO}$ term to a modified Papadopoulos $\left[\mathrm{O}^{-}\right]^{2} /\left[\mathrm{O}^{0}\right]$ term to account for the effects of $\mathrm{Al}_{2} \mathrm{O}_{3}, \mathrm{Fe}_{2} \mathrm{O}_{3}$ and $\mathrm{B}_{2} \mathrm{O}_{3}$ was linear $(\mathrm{NBO})=0.18+2.12 *\left[\mathrm{O}^{-}\right]^{2} /\left[\mathrm{O}^{0}\right]$ with a correlation coefficient of 0.95 . This correlation was based on 62 data points which included the data from Table 2 and Table 3 and the original 13 data points from Papadopoulos. The empirical Hanford sulfate model known as the "rule of five" [20] performed poorly with all the data modeled, e.g. $\mathrm{R}^{2}$ values of $0.16,0.36$, and 0.56 for the at saturation, over saturation and supersaturation data presented in this study.

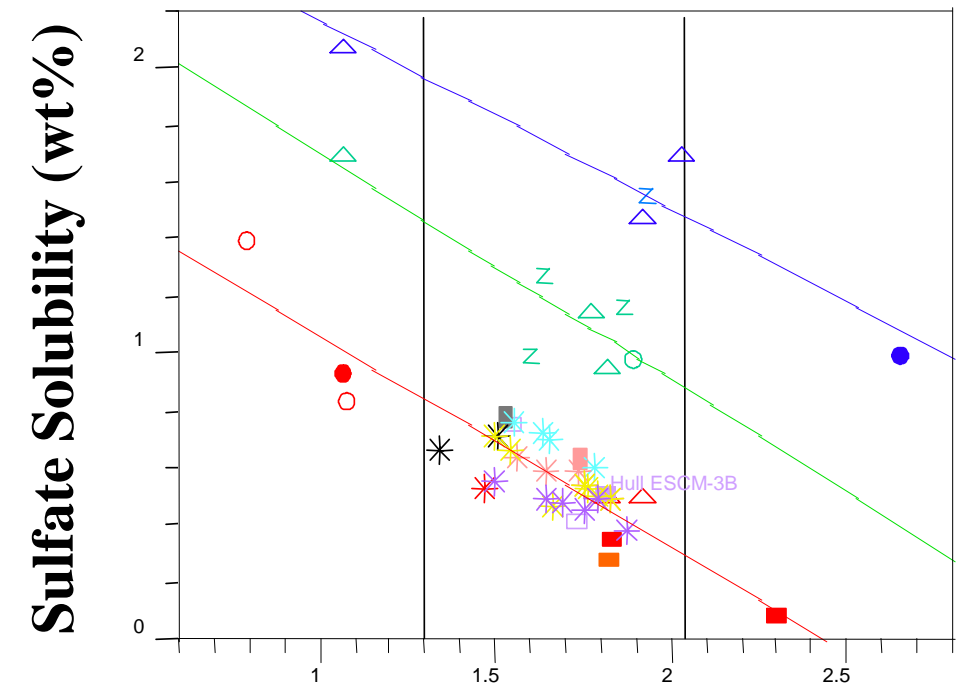

\section{Log Viscosity (poise)}

Figure 2. Sulfate solubility models with validation data for the "as-saturated" correlation (Equation 5) overlain. Note that the sealed crucible sulfate solubilities were adjusted for the lack of volatilization as noted in the text.

\section{CONCLUSIONS}

Sulfate solubility in waste glasses can be modeled as a function of melt polymerization and temperature through the compositionally and temperature dependent DWPF melt viscosity model. This modeling approach was validated in this study and shown to be linear like the Papadopoulos [17] and Ooura and Hanada [18] melt polymerization vs. sulfate models rather than parabolic like the Li et. al. model [19]. Sulfate solubility increases with additional alkali in the models presented in this study which include data from glasses developed for HLW and LAW wastes in agreement with previous studies [17,18,19] but in disagreement with the empirical Hanford "rule of five" sulfate solubility model. 


\section{REFERENCES}

1 M.J. Plodinec and J.R. Wiley, "Evaluation of Glass as a Matrix for Solidifying Savannah River Plant Waste: Properties of Glasses Containing $\mathrm{Li}_{2} \mathrm{O}$," U.S. DOE Report DP-1498, E.I. duPont deNemours \& Co., SRL, Aiken, SC 29808 (February 1979).

2 D.F. Bickford, P. Hrma, B.W. Bowan and P.K. Smith, "Control of Radioactive Waste Glass Melters: II. Foaming and Melt Rate Limits," J. Am. Ceram. Soc, 73 [10] 2903-15 (1990).

3 H.L. Hull, "Trip Report Battelle-PNL Slurry-Fed Melter Test May 17-21, 1982," U.S. DOE Report DPST-82-718, E.I. duPont deNemours \& Co., SRL, Aiken, SC 29808 (Nov. 1982).

4 D.D. Walker, "Sulfate Solubility in DWPF Glass," U.S. DOE Report DPST-86-546, E.I. duPont deNemours \& Co., SRL, Aiken, SC 29808 (October 1986).

5 D.F. Bickford, A. Applewhite-Ramsey, C.M. Jantzen, and K.G. Brown, "Control of Radioactive Waste Glass Melters: I, Preliminary General Limits at Savannah River,” J. Am. Ceram. Soc, 73 [10] 2896-2902 (1990).

6 J.G. Darab, D.D. Graham, B.D. MacIssac, R.L. Russell, H.D. Smith, and J.D. Vienna, "Sulfur Partitioning During Vitrification of INEEL Sodium Bearing Waste: Status Report," U.S. DOE Report PNNL-13588, PNNL, Richland, WA (July 2001).

7 P.G. Walker, "Melter Performance During the Second SCM-2 Precipitate Hydrolysis Test," U.S. DOE Report DPST-85-574, E.I. duPont deNemours \& Co., SRL, Aiken, SC 29808 (August 1985).

8 H.L. Hull, “Trip Report Battelle-PNL Slurry-Fed Melter Tests June, August, October, 1983," U.S. DOE Report DPST-84-518, E.I. duPont deNemours \& Co., SRL, Aiken, SC 29808 (May 1984).

9 H.D. Schreiber, S.J. Kozak, P.G. Leonhard, and K.K. McManus, "Sulfur Chemistry in a Borosilicate Melt, Part I. REDOX Equilibria and Solubility,” Glastech. Ber. 60 [12], 389-398 (1987)

10 C.M. Jantzen, "Characterization of Off-Gas System Pluggages, Significance for DWPF and Suggested Remediation," U.S. DOE Report WSRC-TR-90-205, Westinghouse Savannah River Company, Aiken, SC, 72p. (1991).

11 C.M. Jantzen, "Glass Melter Off-gas System Pluggages: Cause, Significance, and Remediation," Proceed, 5th Intl. Symp. on Ceramics in Nucl. Waste Mgt., G.G. Wicks et. al. (Eds.), Am. Ceram.Soc., Westerville, OH, 621-630 (1991).

12 P. Hrma, J.D. Vienna, W.C. Buchmiller and J.S. Ricklefs, "Sulfate Retention During Waste Glass Melting," Env. Issues and Waste Mgt. Tech. IX, J.D. Vienna and D.R. Spearing (Eds.), Amer. Ceram. Soc., Westerville, OH, VI, 93-99 (2004).

13 M.B. Volf, "Chemical Approach to Glass,” Elsevier Pub. Co., New York, pp.524-543 (1984).

14 H.L. Hull, "Trip Report Battelle-PNL Slurry-Fed Melter Test June 14-23, 1982," U.S. DOE Report DPST-82-1008, E.I. duPont deNemours \& Co., SRL, Aiken, SC 29808 (November 1982).

15 C.M. Jantzen, J.R. Zamecnik, D.C. Koopman, C.C. Herman, and J.B. Pickett, "Electron Equivalents Model for Controlling REDuction/OXidation (REDOX) Equilibrium During High Level Waste (HLW) Vitrification," U.S. DOE Report WSRC-TR-2003-00126, Rev.0, Westinghouse Savannah River Co., Aiken, SC (May 2003).

16 C.M. Jantzen, R.F. Schumacher, and J.B. Pickett, "Mining Industry Waste Remediated for Recycle by Vitrification," Env. Issues and Waste Mgt. Tech. VI, D.R. Spearing, et. al. (Eds.), Amer. Ceram. Soc., Westerville, OH, , 65-74 (2001).

17 K. Papadopoulos, "The Solubility of $\mathrm{SO}_{3}$ in Soda-Lime-Silica Melts," Phys. Chem. Glasses, 14[3], pp., 60-65 (1973).

18 M. Ooura and T. Hanada, "Compositional Dependence of Solubility of Sulphate in Silicate Glasses," Glass Technology, 39 [2], 68-73 (1998).

19 H. Li, P. Hrma, and J.D. Vienna, "Sulfate Retention and Segregation in Simulated Radioactive Waste Borosilicate Glasses," Env. Issues and Waste Mgt. Tech., D.R. Spearing, et. al. (Eds.), Amer. Ceram. Soc., Westerville, OH, VI, 237-245 (2001). 
20 I. Pegg, H. Gan, I.S. Muller, D.A. McKeown, and K.S. Matlack, "Summary of Preliminary Results on Enhanced Sulfate Incorporation During Vitrification of LAW Feeds," VSL-00R3630-1, Rev. 1, Vitreous State Laboratory, The Catholic University of America (2000).

21 J.A. Kelley, "Evaluation of Glass as a Matrix for Solidification of Savannah River Plant Waste," U.S. DOE Report DP-1382, E.I. duPont deNemours \& Co., SRL, Aiken, SC 29808 (May 1975).

22 H. Hull, "Trip Report Battelle-Pacific Northwest Laboratory Slurry-Fed Melter Test, January 25-29, 1982,” U.S. DOE Report DPST-82-387, E.I. duPont deNemours \& Co., SRL, Aiken, SC 29808 (March 9, 1982).

23 F. A. Lifanov, A. P. Kobelev, S. A. Dmitriev, M. I. Ojovan, A. E. Savkin, and I. A. Sobolev, "Vitrification of Intermediate Level Liquid Radioactive Waste," in Env. Remed. and Env. Mgt. Issues, pp241-244, ASME, NY, NY (1993).

24 C.M. Jantzen and M.E. Smith, "Revision of the DWPF Sulfate Solubility Limit," U.S. DOE Report WSRC-TR-2003-00126, Rev.0, Westinghouse Savannah River Co., Aiken, SC (May 2003).

25 Peeler, DK, CC Herman, ME Smith, TH Lorier, DR Best, TB Edwards, and MA Baich. 2004. An Assessment of the Sulfate Solubility Limit of the Frit 418 - Sludge Batch 2/3 System, WSRC-TR2004-00081, Revision 0, Westinghouse Savannah River Company, Aiken, South Carolina.

26 I. Pegg, H. Gan, I.S. Muller, D.A. McKeown, and K.S. Matlack, "Summary of Preliminary Results on Enhanced Sulfate Incorporation During Vitrification of LAW Feeds," VSL-00R3630-1, Vitreous State Laboratory, The Catholic University of American, Washington, DC, (2001).

27 H.D. Schreiber, M.E. Stokes, and C.W. Schreiber, "VMI Final Report - Sulfur in Waste Melts: Enhancing the Capacity of Silicate Melts for Sulfate," VMI Research Laboratories Prepared for GTS Duratek, Inc. and BNFL, Inc. (August 2000).

28 M.H. Langowski, "The Incorporation of P, S, Cr, F, Cl, I, Mn, Ti, U and Bi into Simulated Nuclear Waste Glasses: Literature Study," PNL Report prepared for the Dept. of Energy, Report No. T3C-95111 (1994).

29 C.M. Jantzen, "Relationship of Glass Composition to Glass Viscosity, Resistivity, Liquidus Temperature, and Durability: First Principles Process-Product Models for Vitrification of Nuclear Waste," Proceedings of the 5th International Symposium on Ceramics in Nuclear Waste Management, G.G. Wicks, D.F. Bickford, and R. Bunnell (Eds.), American Ceramic Society, Westerville, OH, 37-51 (1991).

30 B.O. Mysen, D. Virgo, C.M. Scarfe, and D.J. Cronin, "Viscosity and Structure of Iron- and Aluminum-Bearing Calcium Silicate Melts at 1 Atm.," Am. Mineraologist, 70, 487-498 (1985).

31 B.M.J. Smets and D.M. Krol, “Group III Ions in Sodium Silicate Glass. Part 1. X-ray Photoelectron Spectroscopy Study,” Phys. Chem. Glasses, 25 [5], 113-118 (1984).

32 W.L. Konijnendijk, "Structural Differences Between Borosilicate and Aluminosilicate Glasses Studied by Raman Scattering," Glastechn. Ber. 48 [10], 216-218 (1975).

33 S.N. Crichton, T.J. Barieri and M. Tomozawa, "Solubility Limits for Troublesome Components in a Simulated Lowe Level Nuclear Waste Glass," Ceramic Transactions V.61, 283-290 (1995).

34 X. Feng, P. Hrma, M.J. Schweiger, and H. Li, "Sulfur and Phosphorous Solubilities in Phase II Vendor Glass," Spectrum 96 (August 18-23, 1996), Seattle, WA 555-562 (1996).

35 H. Li, J. G. Darab, D.W. Matson, P. A. Smith, P. Hrma, Y. Chen, and J. Liu, "Effect of Minor Components on Vitrification of Low-Level Simulated Nuclear Waste Glasses," in Sci. Basis for Nuclear Waste Mgt. XIX, Vol. 412, Materials Research Society, Pittsburgh, PA (1995). 